\title{
23 \\ LOCAL GOVERNMENT INSTITUTIONS UNDER AUTHORITARIAN RULE IN BANGLADESH
}

\author{
Serdar Yilmaz and Syed Khaled Ahsan
}

Bangladesh is a unitary state with national and local governments. Authoritarianism by the ruling party of the country has several attributes of the autocratization process: brutal party contestation, constrained space for exercising democratic rights, and absence of free and fair elections at the national and local levels (Lührmann and Lindberg 2019). The purpose of authoritarianism is to bring public administration structures at all levels under the control of the national government. The focus of this chapter is to provide a historical account of how the ruling party has constrained local democracy and hindered development of an institutional landscape that is favourable to the extension of political liberties and free and fair elections.

In Bangladesh, the local government system is organized around elected councils and administrative units reporting to the council. In the rural areas, there are three types of local governments: union parishad (UP), upazila parishad (a.k.a. sub-district local government) and zila parishad (a.k.a. district local government). In the urban areas, pourashava (a.k.a. municipality) and city corporation are the two administrative units of the local government system.

The Constitution (The Constitution of the People's Republic of Bangladesh 2019) has mandated an elected local government system without guarantees for autonomy. Articles 59 and 60 of the Constitution envisage locally elected political leadership managing local government administration and work of the public officials in the administrative units. Therefore, the concept of local government institutions (LGIs) refers to the locally elected political leadership and administrative units in the above-mentioned five types of local government. The responsibilities of LGIs include maintaining public order, preparing and implementing plans to deliver local public services and economic development, and imposing taxes to finance local budgets.

Parliament has been entrusted by the Constitution to enact laws to transfer and delegate power to the LGIs and enable them to plan and deliver services to the citizens. The LGIs are meant to provide all amenities to the citizens at the local level according to Articles 59 and 60 of the Constitution (Barakat et al. 2015). The Supreme Court of Bangladesh reiterated the features of the LGIs in a 1992 ruling as electoral accountability towards citizens and public sector accountability to the national government for the powers and responsibilities assigned 
to them together with independent and substantial sources of income (Kudrat-E-Elahi Panir v Bangladesh 1992).

However, the Constitution gives the national government through parliament the power to change the regulatory framework for the local government system. Successive governments have exploited the provisions of the Constitution to dominate the LGIs to consolidate their powerbase. This is an ongoing process of democratic backsliding (Bormeo 2016). Like so many countries, Bangladesh has been experiencing a gradual process of autocratization under a legal façade (Lührmann and Lindberg 2019).

In Bangladesh, the autocratization process has affected the local democracy and LGIs alike. Hence, the LGIs have been facing an uphill struggle to assert their independence and roles in service provisions since independence of the country in 1971. This chapter provides a brief history and evolution of LGIs and local democracy since independence. It starts with a brief description of the process of the taming of local democracy and discusses the issues that impede the growth of the LGIs such as interference of the members of parliament (MPs) and civil servants, elimination of the opposition, uneven level playing field in the elections, monopolization, capacity challenge and financial insolvency.

\section{Adoption of the Constitution and taming of local democracy}

After independence, the Constitution was proclaimed in 1972 and general elections were held in 1973. Bangladesh Awami League (BAL) led by Sheikh Mujibur Rahman, the supreme leader of the independence movement, won the election. Until the assassination of Sheikh Mujibur Rahman by a group of junior army officers on August 15, 1975, the BAL governed the country with an absolute majority.

The first BAL government amended the Constitution on January 25, 1975 to introduce a one-party system. Articles 59 and 60 were rescinded and Article 11 was modified by dropping its last sentence reading, 'and in which effective participation by the people through their elected representatives in administration at all levels shall be ensured.' It was the first blow to the democratic local government system in Bangladesh. Later, the Constitution of the country became subordinated to the martial law proclamations from August 15, 1975.

After the assassination of Sheikh Mujibur Rahman, Bangladesh saw the rule of military dictators from 1975 to 1990. In 1976, Ziaur Rahman, a military ruler and founder of the Bangladesh Nationalist Party (BNP), promulgated the first local government ordinance in Bangladesh. The ordinance recognized three types of LGIs: UP at the union level, thana parishad at the sub-district (or upazila) level and zila parishad at the district level. Later, in 1980, a swanirvar gram sarkar or the self-reliant village government was introduced below the UP level by amending the local government ordinance of 1976. The amendment promoted unanimity to select the gram prodhan or head of the gram sarkar and other eleven members of the village government through consensus of villagers. The village government system was considered as an attempt to politicize the local government system. On May 30, 1981, Ziaur Rahman was assassinated by a group of army officers. After his death, the village government system was abolished by another martial law administrator in July 1982.

In 1982, the introduction of a new tier of LGI, upazila parishad at the upazila or subdistrict level, triggered a strong reaction from political parties. The political parties, including the BNP led by Khaleda Zia, the widow of Ziaur Rahman, and BAL led by Sheikh Hasina, the daughter of Sheikh Mujibur Rahman, resisted the introduction of a new level of LGI by the military government headed by H. M. Ershad. They were concerned about the military government's efforts to consolidate its power at the local level to prolong its rule. The BNP and 
BAL boycotted the first two upazila parishad elections held during the Ershad regime. In 1991, there was an attempt to start the democratization process in the country after the resignation of military dictator, H. M. Ershad and establishment of a non-partisan caretaker government in 1990. The BNP won the national election in 1991 and formed the government. The BNP-led government abolished the administrative tier at the upazila level altogether. The justification for the abolishment was that the upazila parishads were not economically viable for the country as they did not have the capacity to raise revenue from their own sources. In fact, the abolishment of upazila parishads was an attempt to strengthen the control of MPs in the LGIs (which was codified as a law in 1998). The judiciary reinstated the upazila parishad system in 1992. Nonetheless, the BNP government did not enact a legal framework for the upazila parishad during its term. In 1998, the BAL government formally reintroduced the upazila parishad level by enacting the Upazila Parishad Act, 1998. This back and forth of abolishing and reintroducing new tiers had a detrimental impact on the institutionalization of LGIs in Bangladesh.

After transitioning from the anti-democratic military regime to a civilian democratic system, the first general election was held in February 1996 under the BNP-led administration. However, this election was boycotted by the BAL and other opposition political groups. They demanded that the general election in the country be held under a non-party caretaker government. A genuine mistrust grew between the ruling BNP and the opposition political groups as the candidate of the then ruling BNP won in a controversial by-election for a parliamentary seat in March 1994. After that the opposition political groups did not participate in any elections held under the ruling BNP (Hossain 2021). Finally, the BNP succumbed to the demand of the opposition political groups and brought about the election-time caretaker government system. In June 4, 1996, just three months after the February 1996 election, a participatory general election was held under the caretaker government.

Election-time government practice was exercised during the 1996, 2001 and 2008 elections. As a result, transition of power through credible elections started maturing the foundation of the nascent democracy of the country. The BAL and BNP won the elections held under the caretaker governments in 1996 and 2001 respectively. However, the BNP-led government made attempts to manipulate the constitutional bodies to form a caretaker government to have election results in their favour in 2006. That triggered violent street protests organized by the BAL and other opposition political groups. The unrest in the country provoked the military to intervene to form a caretaker government. The general election was delayed until December 2008 and that was won by the BAL. Later, an electoral breakdown happened in 2014 as a consequence of 'a unilateral change in the rules of electoral administration (the elimination of the practice of a caretaker government before the election) that tilted the electoral playing field and triggered an opposition boycott' (Diamond 2015).

The practice of a caretaker government was instrumental to create a level playing field environment in which an election could be held in a free and fair manner without political influence by the outgoing government. We coined the term electoral breakdown in this discourse to describe the assault on the nature of free and fair elections providing de jure institutional guarantees for a level playing field. An uneven playing field is a common feature of contemporary authoritarianism (Way and Levitsky 2020). The departure from the election time caretaker government practice was a breakdown of an established electoral norm, which resulted in political polarization. Consequently, the polarization has exerted authority over all state and non-state institutions in the country and has prevented the consolidation of democracy. The political authoritarianism of both parties, BNP and BAL, has weakened the independence and growth of the LGIs and local democracy. 


\section{Interference in the LGIs}

When the BAL-led government reintroduced the upazila parishad in 1998, they carved out an advisory role for the MPs. According to constitutional scholars, the advisory role of MPs, codified in section 25 of the Upazila Parishad Act, does not conform with Article 59 of the Constitution. The Article states that 'local government in every administrative unit of the Republic shall be entrusted to bodies, composed of persons elected in accordance with law.' The advisory role of the MPs in the upazila parishads disempowers the upazila parishads as an autonomous LGI (Sowdagar 2013). Both the BAL and BNP consider the upazila parishad as an impediment to sustaining their powerbase in the community. They perceive that the upazila system threatens the authority of their MPs. In 2008, the military-backed caretaker government promulgated a new upazila parishad ordinance and abolished the advisory role of the MPs. It is noteworthy that the military-backed caretaker government took the judicious measure to safeguard the local democracy, while successive civilian governments have used their authority (or legal façade) at the centre to choke the democratic system in the country. After the 2008 elections, the BAL-dominated parliament reinstated the role of the MPs in the upazila parishad. The opposition BNP did not oppose that. They expected that this provision would also benefit them when they return to power in the future. With the reinstatement of MPs in the upazila parishads, the elected representatives of the LGIs became hostage to the authority of the MPs and administrative apparatus of the national government. Party loyalty became the precondition for the selection of upazila level positions (Islam 2018).

The country's central bureaucracy is responsible for the civil servants' recruitments, placements, promotions and dismissals. The existing political culture requires the officials posted in the local governments to maintain relationship with the MPs and other leaders of the ruling party. Bureaucrats are often obliged to include beneficiaries recommended by an MP for various social safety net programmes of the government. According to Khan (2015), politicization of the administration has become the norm rather than an exception under highly authoritarian national governments in Bangladesh. As a result, the public administration has lost its edge in delivering public services to the citizens. The Bangladesh Upazila Parishad Association finds the upazila nirbahi (executive) officers as new rulers at the upazila level (Prothom Alo 2021). Their bureaucratic attitudes constrain the elected officials in performing their roles. Many consider neglecting the elected officials of the upazila parishad is a ploy to establish a feudal rule. The civil servants posted in the upazilas and districts are perceived to be more powerful than locally elected leadership. In fact, as the saying goes local bureaucrats do not serve under the LGIs, rather elected representatives of the LGIs are being made to serve under them. Overall, the interference of the civil servants in the LGIs has damaged the fabric between the citizens and LGIs.

Neither the ruling BAL nor the opposition BNP had a principled stand on the independence of the upazila parishad. The BNP did not oppose the advisory role of the MPs in the upazila parishad in the first place, expecting to use it for their advantage. Now they have voiced their concern of the section 25 of the upazila parishad act of 1998. The opposition political groups have had an insignificant representation in parliament during the last two terms, and the ruling BAL did not agree with their demand for dropping section 25. In 2019, an MP of the opposition BNP raised the issue of repealing section 25 in parliament. The government ruled out any possibility of removing the roles of the MPs in the upazila parishad from the upazila parishad act of 1998 (UNB News 2019). Parliament is unlikely to allow the LGIs to freely perform their constitutionally mandated roles, away from the control of a prevailing authoritarian 
environment. The administrative apparatus of the state remains loyal to the national government and political masters, and lacks respect for the elected officials of the LGIs. The Local Government Division's (LGD) holding of power to exercise control over the activities of the LGIs and mandatory advisory function MPs has further complicated the situation for the LGIs (As-Saber 2009). Thus, the LGIs have to remain heavily dependent on the national government. Their transparency and accountability to the citizens are compromised. They could not be self-governing institutions but an extension of the national government (Panday 2011).

The interference of any officials or an MP who are elected in the LGIs contradicts the verdict of the apex court of Bangladesh. The Chief Justice of the country described the situation in a full court judgment as local governments are '... meant for management of local affairs by the locally elected persons. If government officers or their henchmen are brought to run the local bodies, there is no sense in retaining them as Local Government bodies' (Kudrat-E-Elahi Panir v Bangladesh 1992).

\section{Elimination of the opposition at the local level}

The BNP and other opposition political groups paid a high price for the unprincipled compromise with the ruling BAL in trying to dominate upazila parishad by granting the MPs an advisory role. Just a few months ahead of the 2014 national election under the BAL-led administration, the victory of the opposition BNP-backed mayors in the city corporation elections in June-July 2013 rendered the BAL anxious. The opposition political groups started expounding the results of the city elections as an indication of citizens' support towards the demand for an election-time caretaker government to conduct the 2014 national election. The BNP and other opposition political groups declared boycotting the national election unless the election-time caretaker government system was reinstated. The elected officials of various LGIs from the opposition groups were active in the street protests demanding reinstatement of the caretaker government system to hold the national election in 2014. The BAL government accused them in many cases over their suspected involvement in the political violence like arson attacks, sabotage, vandalism, etc. Although, the government could not prove any allegations brought against them in court, they started targeting opposition-controlled local governments. The ruling BAL did not want to take chances and decided to abandon the election time caretaker government system. The targeting of the elected officials of the LGIs who had won from the opposition groups set a new precedent of autocratization by the BAL-led government in the country. As a result, the BAL had undermined the political opposition and extended its patronage roots further into the local communities to consolidate its position to cling to power (Lewis and Hossain 2019).

The interference of the government in the city corporations and other LGIs has jeopardized the connections between the citizens and LGIs and affected the service delivery to the citizens. The interference has become incremental and led to shrinking of the democratic space in the local governments and accountability of the LGIs to the citizens. In Khulna, Sylhet, Rajshahi, Gazipur and Barisal, for example, candidates from the opposition BNP won elections in the city corporations in the 2013 elections. However, the elected mayors in Sylhet, Rajshahi and Gazipur could hardly perform their mayoral roles. They were suspended on several occasions under section 12 of the Local Government (City Corporation) Act, 2009, which provides a legal basis for the suspension of a mayor or a councillor if he/she is convicted or charge-sheeted in a criminal case. While many councillors of different city corporations who belonged to the ruling BAL and were charge-sheeted in criminal cases were allowed to perform their duties, opposition parties faced harassment from the authorities. The government suspended twenty-four mayors 
of city corporations and municipalities, twenty-eight upazila chairmen, thirteen upazila vice chairmen and more than 150 union parishad chairmen and members between 2014 and 2015 (New Age 2017). They were charge-sheeted in different cases like arson and murder, but none was convicted by the courts in the end. The charges brought against the elected officials were apparently politically motivated. The Rajshahi mayor challenged the legality of the suspension order against him in 2017. The supreme court found an arbitrary exercise of discretionary power to suspend the mayor. Also, the court directed the LGD to inform the authorities concerned in the government and parliament to take steps to amend the provision on suspension of city mayors and councillors (The Daily Star 2017). The incidents of suspension of the elected officials have not stopped after the verdict nor has the government or parliament taken any measures to amend the act. The ruling party has been using the section of the act as means to control or diminish the power of the elected officials from the opposition political groups.

\section{Elections on an uneven playing field}

Amendments were made in all local government acts to introduce party-based local government elections in 2015. However, the party-based local government elections have so far failed to boost a constructive political climate. The UPs were the first LGI to go for party-based elections from March 3 to June 4, 2016. Incidents of selling of party nominations by the leaders of the BAL, BNP and others were rampant as the system created a scope for the local party leaders to get involved in corrupt practices (Panday 2019). In the UP elections, 145 people were killed, a record 214 were elected uncontested and 212 of them were from the ruling BAL (The Daily Star 2016).

In 2016, the first ever zila parishad elections were held in December. Since the Zila Parishad Act, 2000 does not have a provision for universal adult franchise, the 21-member body of the leadership of zila parishads was indirectly elected by the elected officials of other LGIs of the district. Although the voting in the zila parishads elections was held in a non-partisan manner (unlike the other elections for the LGIs), the candidates were aligned with political parties. Nearly all electorates for the zila parishads belong to the ruling BAL. Candidates who belonged to the ruling party won all positions in the zila parishads. The candidates from the opposition political groups hardly had any chance to be elected for any positions in the zila parishads. Hence, no opposition political groups dared to participate in the elections.

The elections of the LGIs are no more trustworthy, credible and competitive as a whole. Elections since 2016 have only deepened the feeling of despair among the general public and greatly weakened the country's democratic polity. The opposition BNP boycotted local elections in the first half of 2019, and the country saw an historically low turnout of voters on the polling day (Freedom House 2020). Since the eleventh parliamentary elections held on December 30, 2018, the voter turnout has been declining. The voter turnout for the Dhaka North City Corporation on February 28, 2019 was only 30\%. It was 40\% in the five-phase upazila parishad elections in 2019. On February 1, 2020, the voter turnouts were $25.85 \%$ and $29.07 \%$ for the Dhaka North City Corporation and Dhaka South City Corporation elections. The Daily Star reported an astonishingly low number of voters turned out at the centres in the city corporation elections in Dhaka. The poor voter turnout dampened the spirit common in elections in the country. Almost all the poll observers at the centres were for the mayoral and councillor candidates from the ruling BAL (The Daily Star 2020).

The poor voter turnout is a direct result of low levels of public trust in the election commission. The highly politicized election commission of the country failed in holding any impartial local government election. The commission is widely using the electronic voting 
machines (EVMs) in the elections. The EVM system in Bangladesh has no provision for a voter verifiable paper audit trail (VVPAT) or verified paper record (VPR) (Karim 2020). Introduction of the VVPAT could give confidence to the voters and the contesting parties against possible election fraud and malfunction. A majority of the opposition political parties and citizens' groups in Bangladesh are concerned by using the EVMs as the election officials lack credibility. However, the ruling BAL favours using the EVMs in the elections.

The government machinery controls each of the key stages of any contested election, such as campaigning, polling and declaring results. The end result is such that the elections are participatory, while their outcomes are not credible at all. The level playing field does not exist for the candidates in the local government elections. The election observers of an opposition candidate are not allowed to stay in the polling stations. The pattern has been common for the local government elections in Bangladesh.

The election preparation and campaign by opposition candidates are often obstructed by filing frivolous lawsuits against them. Candidates from the opposition political groups were prevented from contesting the municipal polls in 2015. About 3,000 activists of the opposition BNP were arrested in a single week before the elections (Mazumdar 2016). The trend has not changed as the municipal elections were taking place in January 2021. Violence and irregularities in the polling process made candidates from the BNP withdraw from the elections (New Age Online 2021).

Elections that were held in various LGIs of the country between December 2020 and January 2021 have made it clear that the election process has become one-sided and less competitive. The election commission, civil administration and law enforcing agencies have all worked in favour of the ruling party candidates in the municipalities and city corporation. All of which had a detrimental impact on citizens' participation in local democracy. To give one example, the voter turnout in the Chattogram City Corporation election held on January 27, 2021 was only $22.52 \%$.

The BAL-backed mayoral candidate got all votes in 13 polling centres, while the BNPbacked candidates did not get any vote in 22 centres in the Chattogram City Corporation election. The ruling BAL-backed candidates and dissident BAL candidates won all the positions there. Elections in Chattogram, the second largest city of the country, mirrored what had happened in the elections in 83 municipalities on December 28, 2020 and January 16, 2021. The ruling BAL won 18 out of 23 and 40 out of 60 mayoral positions on December 28, 2020 and January 16, 2021 respectively. Intimidation of the opposition candidates and their election agents, obstruction of voters, capturing of polling stations, stuffing of ballot papers in ballot boxes and violence by the ruling BAL activists marred all the elections in the LGIs (Hossain 2021; New Age 2021).

In some instances, midway through the election day, the opposition candidates withdrew from the elections with allegations of irregularities in the polling process. According to Riaz (2019), the election commission in collusion with the civil administration, law enforcing agencies and ruling BAL party activists ensured victory to the ruling party.

Out of 40 candidates for the councillor positions nominated by the opposition BNP for the Chattogram City Corporation elections held on January 27, 2021, some 29 were accused in criminal offences. The number was only four for the candidates of the ruling BAL. The charges brought against the opposition political activists were 'gayebi' or false according to the candidates from the BNP. Bringing charges against the political rivals serves as a strategy of the ruling party to obstruct them from election campaigning (Ghosh and Hasan 2020).

More recently, accusing the ruling party of winning the local elections by vote rigging and using muscle power and civil administration, the main opposition BNP decided to boycott the 
upcoming local elections in April 2021 (New Age 2021). It is very likely that the elections in 4,571 UPs scheduled to start in April 2021would be one-sided and candidates loyal to the ruling party would win in all the UPs.

The unfair and dubious elections have implications for democracy at the local level and service delivery to the citizens by the LGIs. The citizens' ability to hold the elected officials accountable for their service delivery is severely constrained. A nomination of the ruling party often guarantees a victory to a candidate in the election. The outcome is poor planning and implementation of development schemes and selection of beneficiaries for different services. As a result of these unfair and dubious elections, the local politicians have become more loyal to the ruling party than to the people they are supposed to be serving.

The Bangladesh country report of Freedom House has mentioned the concerns of the opposition political groups and international election observers of the lack of independence of the election commission and its biased attitudes. Unfair election practices favoured the ruling party in the country's general elections held in 2018 (Freedom House 2020). On December 14, 2020, a group of 42 distinguished citizens requested the President of the Republic form a Supreme Judicial Council to probe graft allegations against election commission officials. They requested they investigate "irregularities in the 11th Parliamentary Election and elections in Dhaka (North and South) City Corporations, Khulna City Corporation, and Gazipur City Corporation' (Tithila 2020). The election commission and executive branch of the government will not be able to work independently and with integrity as long as they serve under an authoritarian government. Diamond (2015) observed that democracy would not return anytime soon to the country. The outcomes of the elections evidently strengthen the control of the ruling elites of the country over the LGIs at the cost of the independence and growth of the latter.

\section{Monopolization of the LGIs}

The LGIs are greatly politicized as a result of the confrontational politics and disrespect for democratic norms and institutions. Monopolization of the local government system and its resources has reduced the effectiveness of the LGIs in the country. This monopolization by a ruling party is termed partyarchy (Coppedge 1994). The partyarchy has adversely affected the service provisions in the LGIs and undermined democracy at the local level. As a result, service provisions by the LGIs are being marred by irregularities and corruption. A number of elected officials in different LGIs allegedly embezzled government cash aid and relief for the targeted beneficiaries during the ongoing coronavirus pandemic in the country (Dhaka Tribune 2020).

The monopolization of all state institutions and resources including the LGIs by the party in power has weakened the formal accountability mechanisms of the LGIs and put governance in crisis (Osman 2010). The ruling BAL has succeeded in capturing the majority of the LGIs of the country through coercive and undemocratic means. Coercion in the elections process ensured control of the ruling party over the LGIs at the expense of local democracy. The coercive force has also greatly undermined the legitimacy of the elected bodies of the LGIs in the country.

At present, over $90 \%$ of the municipal mayors and upazila parishad and UP chairmen are from the BAL. Out of 12 city corporations, only two have mayors from the main opposition party, BNP. The loyalty of the elected officials to their party bosses is damaging the checks and balances of democracy. The LGIs remain engaged in implementing the agenda set by the national government and defending the interests of the ruling BAL. 


\section{Two major problems to tackle in order to make local democracy work}

In Bangladesh, the overriding problem for making local democracy work is the lack of capacity of LGIs, which is a function of autonomy. When local governments are assigned to perform certain functions, they should be given sufficient resources to fulfil their obligations together with freedom to design their own policies (Widmalm 2008). Otherwise, without autonomy to exercise discretion local governments will never develop capacity. According to Widmalm, ' $[t]$ he most central aspect of decentralization concerns the extent to which real power is moved downwards in the administrative or democratic structure' (Widmalm 2008: p. 44).

Although the LGIs in Bangladesh have been assigned to perform important responsibilities, they lack the means to independently perform those functions. This can be attributed to the failure of the national government to empower the elected officials with necessary authorities, resources and responsibilities to establish control over local bureaucracy and perform their duties. The LGIs remain merely a playground for the political parties in Bangladesh to exhibit their strengths every five years during the elections (Ahmed 2019). Configurations of the LGIs have often been changed for strengthening the powerbase of the ruling party of the country. The political dividends of changes in the LGIs to ruling parties are significant. Often the reasons for reconfiguration of the LGIs are to increase popularity in the voting population and create new spaces to accommodate more party leaders.

The UPs are one of the oldest democratic institutions in Bangladesh, predating the independence of the country, although, they are not well staffed and well resourced. The Local Government (Union Parishad) Act, 2009 provides a detailed organizational structure and lists positions to be filled. However, the national government controls the recruitment, salary and benefits, disciplinary measures etc. of the civil servants posted in the UPs. The UPs are allowed to appoint additional staff with prior approval of the government. They lack resources to finance the salary and allowances of any additional staff. In reality, therefore, no UP can afford to appoint any staff on their own. Until 2009, the secretary was the only full-time staff in UPs. The offices of the deputy commissioner at the district level have started recruiting the accounts assistants for the UPs in 2019. Out of 4,571 UPs, only a few now have two full-time staff.

According to the UP act, the government was required to specify the controlling power of UPs over the civil servants working at the union level through notifications. Yet no government has come forward to assign the civil servants working at the unions under the administrative control of the UPs to augment the staffing capacity. Thus, the UPs lack managerial capability and resources to provide service delivery to the citizens (Aminuzzaman 2010).

At the zila parishad level, the situation is more dire. Despite the elections that took place in the zila parishads for the first time in the country, the locally elected political leadership could not get a visible grasp of the local bureaucracy. The MPs and civil servants based in the district headquarters have been playing a major role in decision making since 2009 and they continue to do so (Ahmed 2016).

The second major hurdle in front of local democracy is the lack of financial resources for LGIs to perform their constitutionally assigned functions. The financial insolvency and politicization of financing prevent the LGIs developing the necessary capacities to be autonomous local government units in the service of their citizens. The ruling parties have done very little to improve the intergovernmental fiscal system. The share of local government expenditures in the national budget for the fiscal year 2020/21 is only 7\% (Macroeconomic Wing 2020). As there are duplicative distributions of functional responsibility among the LGIs and between the LGIs and administrative apparatus, it is difficult to estimate the expenditure needs of the LGIs. The revenue fund and development fund are two sources of funds for the LGIs. They 
are surviving on budgetary support in the form of grant-in-aid from the national government and occasional assistance from the international donors. In the fiscal year, 2017/18, the UPs, pourashavas and city corporations spent USD 6.1, USD 18.0 and USD 44.2 per resident respectively (World Bank 2020). Although LGIs have an entitlement over the share of national resources, dependence on national government transfers has resulted in the losing of autonomy by the LGIs (Siddiqui 2014).

The grant-in-aid doesn't judiciously consider population, area, special needs and past performance of an LGI to allocate and disburse resources. At present, the World Bank-financed Local Governance Support Projects (LGSP) have been providing direct block grants to all UPs and a few municipalities. The LGSPs aimed at establishing an efficient and transparent intergovernmental fiscal system. Nonetheless, the LGSP model for intergovernmental transfer remained limited mainly to the UPs and dependent on external financing. The tax base of the LGIs could be strengthened by empowering them to take more control of the tax collection in their respective constituencies. Taxes on property transfer, land development and proceeds from markets, water estates, issuance of licences etc. are some potential sources of revenues for the LGIs. The distribution of authority among different LGIs on tax collection in some areas like leasing, issuing licences etc. lacks clarity too. The tax base of the LGIs remains insufficient to support service delivery to the citizens. The government could not give an enabling environment to the local government system to improve the prevailing situation.

Loyalty of the elected officials to the ruling party always put the LGIs in an advantageous position to receive financial support from the national government. In addition to accessing financial resources, the loyalty gives them impunity in case of irregularities too (Sabina, Khan and Badiuzzaman 2015). On the other hand, local jurisdictions managed by opposition parties are penalized. In the last five years, the mayors elected from the opposition BNP in thirty municipalities got less allocation for their projects than the mayors from the ruling BAL (Rahman 2021). Politicization of the financing deprived the citizens of municipal services who elected mayors from the opposition political groups.

The discriminatory behaviour of the government has ramifications for the future of local democracy. The ability of the local governments to respond to the preferences of its citizens is inseparably tied to the democratic system and its practice of a country. The opposition political groups would be inclined to mobilize their supporters for bigger protests if the authoritarianism is further entrenched in the country and the ruling BAL is not willing to give any of the levers of power. The protests by the opposition in Bangladesh often lead to political violence in the end. Ultimately, the LGIs will be losing their relevance in the local development and growth of democratic polity at large.

\section{A future to look forward to?}

The local governments are described in general terms in the Constitution of Bangladesh and they do not enjoy constitutional guarantees (Ahmed 2016). Although parliament is entrusted with the task of bringing the legal framework for the LGIs, there are questions about the independence of the legislative branch from the executive branch. The existing legal frameworks for the local governments have kept back most of the governing power with the national government, as the attributes of a unitary state are very dominant in the psyche of the ruling elites. Therefore, in order to safeguard the tenets of local democracy, the LGIs need some constitutional guarantees for autonomy and access to financial resources to deliver services to the citizens.

Few acts related to local government have provisions for the unelected officials to interfere in the LGIs. The upazila parishad act is one of the examples of abusing the legislative 
authority of the MPs. The act made it mandatory for the upazila parishads to accept their advice (Mazumdar 2010). The apex court of the country showed judicial activism in interpreting the constitutional principles of local-level democracy: 'Parliament is not free to legislate on local government ignoring Articles 59 and 60' (Kudrat-E-Elahi Panir v Bangladesh 1992).

Bangladesh has never witnessed any initiative of two major parties, BAL and BNP, to establish an effective self-governing local government system. The LGIs merely remain as extensions of the national government with limited citizens' engagement. The interference of the ruling party to capture the LGIs has increased manifold during the last decade. Yet, the introduction of the party-based local government system can potentially become a blessing in disguise. Hankala, Martinez-Vazquez and Rodriguez (2019) emphasized the need for balancing between democratic decentralization and party integration. Notwithstanding, democratic decentralization entails competitive local elections to generate accountability and incentivize local leaders to improve governance. On the other hand, integrated parties would pass down national preferences to the local level (Hankala, Martinez-Vazquez and Rodriguez 2019). The country would await an environment for the fair, honest and free elections for the LGIs.

One of the most destructive legacies of the authoritarian rule in Bangladesh would be numerous attempts to monopolize and weaken the local government system. Unqualified leaderships are brought in by the LGIs who are chosen for their political loyalty to the ruling party. Also, the influence and dominance of the self-serving bureaucrats over the LGIs have now increased manifold. Attempts to centralize roles and responsibilities of the LGIs have shrunk the democratic spaces and exposed the continuing autocratization trend in the country. A vibrant local government system in Bangladesh could thwart the ongoing autocratization process and pave the way for a transition to a liberal democratic rule.

\section{Glossary}

1. Union - The lowest tier of administration in Bangladesh

2. Parishad-Council

3. Union Parishad - Union Council, a local government institution

4. Upazila-Sub-district, the second tier of administration in Bangladesh

5. Upazila Parishad - Upazila Council, a local government institution

6. Zila-District, the administrative tier above sub-district in Bangladesh

7. Zila Parishad - District Council, a local government institution

8. Pourashava - Municipality, an urban local government institution

9. City Corporation - Local government institution in a large city

10. Constitution - Constitution of Bangladesh

11. Swanirvar gram sarker - Self-reliant village government

12. Non-partisan caretaker government - Election time government in Bangladesh

13. Electoral breakdown - a term describing assault on de jure safeguard mechanisms for free and fair elections

14. Upazila nirbahi officers - Upazila Executive Officer

15. Local Government Division - A national government agency under the Ministry of Local Government, Rural Development and Cooperatives

16. Partyarchy - Dominance over the various state and non-state institutions by the political parties

17. Gayebi-Unsubstantiated 


\section{Bibliography}

Ahmed, Tofail (2016a). 'Zila Parishad in Bangladesh: Urgency for an election.' The Daily Star, August 24. Available at: www.thedailystar.net/op-ed/politics/zila-parishad-bangladesh-1274479 (Accessed January 4, 2021).

Ahmed, Tofail (2016b). Bangladesh: Reform Agenda for Local Governance. Dhaka: Prothoma Prokashan.

Ahmed, Wasi (2019). 'Empowering local government institutions.' Available at: www.thefinancialexpress.com.bd/ views/empowering-local-government-institutions-1568732464 (Accessed February 1, 2021).

Aminuzzaman, Salahuddin M. (2010). Local Government and Development in Bangladesh: Lessons Learned and Challenges for Improving Service Delivery of Union Parishad. Bangladesh: Local Government Division.

As-Saber, Sharif N. \& Rabbi, Md Fazle (2009). 'Democratisation of the Upazila Parishad and Its Impact on Responsiveness and Accountability: Myths versus Realities.' JOAAG, 4 (2), pp. 53-71.

Barakat, Abul. et al. (eds.) (2015). Local Governance and Decentralization in Bangladesh: Politics and Economics. 1st edition. Dhaka: Pathak Shamabesh.

Bermeo, Nancy (2016). 'On Democratic Backsliding.' Journal of Democracy, 27 (1): pp. 5-19. 10.1353/ jod.2016.0012.

The Constitution of the People's Republic of Bangladesh, 2019. Available at: http://bdlaws.minlaw.gov.bd/ act-367.html (Accessed January 12, 2021).

Coppedge, Michael (1994). Strong Parties and Lame Ducks: Presidential Partyarchy and Factionalism in Venezuela. Stanford: Stanford University Press.

The Daily Star (2016). '145 killed in 'ghoulish' UP polls: Shujan,' The Daily Star, June 16, 2016. Available at: www.thedailystar.net/politics/145-killed-union-parishad-polls-shujan-1240543 (Accessed December 24, 2020).

The Daily Star (2017). 'Suspension, once again.' The Daily Star, July 7, 2017. Available at: www.thedailystar.net/ frontpage/gazipur-city-corporation-gcc

The Daily Star (2020). 'Voters keep off', The Daily Star, February 2, 2020. Available at: www.thedailystar.net/ frontpage/dhaka-city-elections-2020-voters-keep-1862272 (Accessed January 10, 2021).

Dhaka Tribune (2020). 'Relief embezzlement: 100 public representatives suspended till date.' Dhaka Tribune, June 17. Available at: www.dhakatribune.com/bangladesh/2020/06/17/relief-embezzlement-100-publicrepresentatives-suspended-till-date (Accessed December 23, 2020).

Diamond, Larry (2015). 'Facing Up to the Democratic Recession.' Journal of Democracy 26 (1): pp. 141-155.

Freedom House (2020). 'Freedom in the world'. Available at: https://freedomhouse.org/country/bangladesh/ freedom-world/2020 (Accessed January 11, 2021).

Ghosh, Sujon and Tasneem Hasan (2020). 'More cases against BNP candidates' (in Bangla), Prothom Alo, April 12. Available at: https://bit.ly/3C0nRGa (Accessed January 3, 2021).

Hankala, Charles R., Jorge Martinez-Vazquez and Raul Alberto Ponce Rodriguez (2019). Local Accountability and National Coordination in Fiscal Federalism: A Fine Balance. UK: Edward Elgar Publishing Limited and USA: Edward Elgar Publishing, Inc.

Hossain, Akbar (2021). 'February 15 Election: The context and modality of the controversial and one-sided election in 1996 during the time of Khaleda Zia' (in Bangla), BBC Bangla, Dhaka. February 15, 2021. Available at: www.bbc.com/bengali/news-56054285.amp (Accessed February 15, 2021).

Hossain, Md. Anwar and Pranab Kumar Baul (2021). 'AL didn't want voter turnout, BNP unable, EC silent.' Available at: https://en.prothomalo.com/bangladesh/politics/al-didnt-want-voter-turnoutbnp-unable-ec-silent (Accessed January 30, 2021).

Islam, Mohammad Tarikul (2018). 'Cooperation or interference: MP's role in local government.' The Daily Star, December 11. Available at: www.thedailystar.net/opinion/news/cooperation-or-interference-mpsrole-local-government-1671871 (Accessed December 13, 2010).

Karim, Riadul (2020). 'The BNP candidates lost security deposit in 12 municipalities' (in Bangla). Prothom Alo, December 30. Available at: https://bit.ly/3E7Gavb (Accessed January 1, 2021).

Khan, Akbar Ali (2015). Gresham's Law Syndrome and Beyond: An Analysis of the Bangladesh Bureaucracy. Dhaka: University Press Limited.

Kudrat-E-Elahi Panir Vs. Bangladesh [1992] 44 DLR (AD) (1992) (Appellate Division (Civil) of the Supreme Court of Bangladesh), p.319.

Lewis, David \& Hossain, Abul (2019). 'Local Political Consolidation in Bangladesh: Power, Informality and Patronage.' Development and Change. 10.1111/dech.12534.

Local Government (Union Parishad) Act, 2009. Available at: http://chandanaish.chittagong.gov.bd/site/ law_policy/b2e85554-2147-11e7-8f57-286ed488c766 (Accessed November 30, 2020).

The Local Government (City Corporation) Act (2009). Available at: www.clcbd.org/document/535.html (Accessed January 12, 2021). 


\section{Serdar Yilmaz and Syed Khaled Ahsan}

Lührmann, Anna and Lindberg, Staffan I. (2019). 'A Third Wave of Autocratization Is Here: What Is New About It?’ Democratization, 26 (7): pp. 1095-1113, DOI: 10.1080/13510347.2019.1582029.

Macroeconomic Wing (2020). 'Monthly Report on Fiscal Position.' October 2020. Finance Division Ministry of Finance, Government of the People's Republic of Bangladesh.

Mazumdar, Badiul Alam (2010). Local Governance and Political Reform: Keys to Poverty Reduction. Dhaka: Agamee Prakashani, pp. 19-30.

Mazumdar, Badiul Alam (2016). 'How fair were the Paura Elections?', The Daily Star, January 27. Available at: www.thedailystar.net/op-ed/politics/how-fair-were-the-paura-elections-207748 (Accessed January 10, 2021).

New Age (2017). 'Suspension of elected official is autocratic.' New Age, April 4. Available at: www.newagebd.net/ article/12672/articlelist/323/article/article/index.php (Accessed November 18, 2020).

New Age (2021). 'BNP to boycott upcoming UP elections.' New Age, February 28. Available at: www. newagebd.net/article/131399/bnp-to-boycott-upcoming-up-elections (Accessed February 28, 2021).

New Age Online (2021). 'Municipality polls end amid violence, irregularities.' New Age, January 16. Available at: www.newagebd.net/article/127342/municipality-polls-end-amid-violence-irregularities (Accessed January 16, 2021).

New Age Opinion (2021). 'Chattogram city elections betray failures of EC, govt.'Available at: www.newagebd.net/ article/128586/chattogram-city-elections-betray-failures-of-ec-govt (Accessed January 30, 2021).

Osman, Ferdous Arfina (2010). 'Bangladesh Politics: Confrontation, Monopoly and Crisis in Governance.' Asian Journal of Political Science, 18 (3): pp. 310-333.

Panday, Pranab Kumar. (2011). 'Local Government System in Bangladesh: How Far is it Decentralised?', LEX LOCALIS - Journal of Local Self-government, 9 (3): pp. 205-230.

Panday, Pranab Kumar (2019). 'Party-based Local Government Election: Pains and Gains,' Daily Sun, March 20. Available at: www.daily-sun.com/printversion/details/378876/Partybased-Local-GovernmentElection:-Pains-and-Gains (Accessed December 24, 2020).

Prothom Alo (2021). NOs are behaving like a ruler, said the public representatives' (in Bangla), Prothom Alo, January 2. Available at: https://bit.ly/3k6oeJf (Accessed January 3, 2021).

Rahman, Shamsur (2021). 'The BNP mayors are leaving behind' (in Bangla). Prothom Alo, January 12. Available at: https://bit.ly/2VE9c44 (Accessed January 12, 2021).

Riaz, Ali (2019). Voting in a Hybrid Regime: Explaining the 2018 Bangladeshi Election. Singapore: Palgrave Macmillan.

Sabina, Nazme, Sayeedul H. Khan and M. Badiuzzaman (2015). 'Local Government by Whom,' in Barakat, Abul, et al., editors. Local Governance and Decentralization in Bangladesh: Politics and Economics. Dhaka: Pathak Shamabesh, pp. 61-75.

Siddiqui, Kamal (2014). Local Government in Bangladesh. Dhaka: The University Press Limited.

Sowdagar, Mezbah-Ul-Azam (2013). 'Challenges of Local Governance: A Study on New Upazila Administration in Bangladesh.' Jagannath University Journal of Social Sciences, 1 (1-2): pp. 56-73.

Tithila, Kohinur Khyum (2020). ' 42 citizens call for Supreme Judicial Council to probe graft allegations against EC,' Dhaka Tribune, December 19. Available at: www.dhakatribune.com/bangladesh/2020/ 12/19/42-citizens-call-for-supreme-judicial-council-to-probe-graft-allegations-against-ec (Accessed December 20, 2020).

UNB News (2019). 'No plan to drop section 25 from UZ Parishad Act.' UNB, September 11. Available at: https://unb.com.bd/category/bangladesh/no-plan-to-drop-section-25-from-uz-parishad-act/ 27992 (Accessed December 26, 2020).

Upazila Parishad Act (1998). Available at: http://bdlaws.minlaw.gov.bd/act-827.html (Accessed February 2, 2021).

Way, Lucan Ahmad and Levitsky, Steven (2020). 'Why Democracy Needs a Level Playing Field.' Journal of Democracy, 21 (1): pp. 57-68.

Widmalm, Sten (2008). Decentralization, Corruption and Social Capital from India to the West. First Edition, New Delhi: Sage Publications.

World Bank (2020). 'Improving Local Governance and Service Delivery in Bangladesh: Role of Local Government Finance.' Available at: https://documents1.worldbank.org/curated/ en/150821592287566995/pdf/Improving-Local-Governance-and-Service-Delivery-in-BangladeshThe-Role-of-Local-Government-Finance.pdf

Zila Parishad Act (2000). Available at: http://bdlaws.minlaw.gov.bd/act-841.html (Accessed February 2, 2021). 